\title{
Multimedia Courseware for Teaching Arabic Vocabulary: Let's Learn from the Experts
}

\author{
Nurkhamimi Zainuddin ${ }^{1, *}$, Muhammad Sabri Sahrir ${ }^{2}$ \\ ${ }^{1}$ Faculty of Major Language Studies, Islamic Science University of Malaysia, Malaysia \\ ${ }^{2}$ Department of Arabic Language and Literature, Kulliyyah of Islamic Revealed Knowledge and Human Sciences, International Islamic \\ University Malaysia, Malaysia
}

Copyright $(2016$ by authors, all rights reserved. Authors agree that this article remains permanently open access under the terms of the Creative Commons Attribution License 4.0 International License

\begin{abstract}
This study attempts to analyze and evaluate theories and design principles for the design and development of multimedia program for teaching and learning Arabic vocabulary among non-native speakers. In this paper, the researchers mentioned about the research tools, sampling technique and steps as well as population which are related to the design and development process of multimedia courseware which were conducted among the experts in the subject matters (SME). The study proposes the implementation theories of social constructivism by Vygotsky (1978), second language acquisition by Krashen (1984), multimedia learning by Mayer (2001) and ADDIE instructional model by Dick \& Carey (1990). The feedbacks were gathered from various SME experts in teaching Arabic as a second language (TASL) and instructional design (ID) who have participated in the study. This paper has concluded the initial theories of design and development of multimedia learning courseware as proposed by the SMEs as outcome of this paper that can be used by the researcher in the design and development processes of related multimedia learning courseware in language learning
\end{abstract}

Keywords Design and Development, Multimedia Program, Theories and Design Principles, Arabic Vocabulary, Arabic for Non-native Speakers

\section{Introduction}

The Internet has long been utilized to facilitate language teaching and learning process due to its capabilities, particularly its abilities to provide a one-stop source of information and opportunities for language learners to communicate among themselves either synchronously through chat and online messenger or asynchronously through bulletin board and email. There are many benefits as mentioned by researchers from the use of the Internet in education. It serves the objectives of strengthening self-learning and attracting the students in an interesting way as students can reduce their learning time and increase their achievement [1]. Technology in general and the Internet in particular have invaded all areas of modern life, the economy and the media, politics, and communications, as the Internet today has become a way of prominent communications means [2].

The Centre for Languages and Pre-University Academic Development (CELPAD), International Islamic University Malaysia (IIUM) has been playing its role in teaching and learning for students at the university level [3]. In order to achieve the objectives of the center in language teaching, CELPAD used a number of teaching aids and modern learning tools such as e-books and advanced multimedia program like Facebook and YouTube and Moodle. The centre believes that this program from the Internet can provide teachers and students new experiences in the process of Arabic language teaching and learning [4]. The primary goal of this centre is continuous improvement to improve students' proficiency for most of the skills and achieve educational goals. It is necessary to keep up with the technological development, live with it and use it in teaching and learning.

The teaching of Arabic language can no longer rely solely on traditional methods of learning, such as note taking and lecturing, which are still largely preferred among Arabic lecturers as mentioned by Mohd Feham and Isarji [4]. The researchers' early analysis and observation entail that the lack of use of instructional technologies in teaching and learning Arabic has hindered the memorization process of Arabic vocabularies taught in the classroom. The problems and arising needs of using instructional technologies in Arabic language learning such as Arabic courseware have been discussed and proposed by Mohd Feham and Zawawi [5][6].

This study was conducted to explore the potential of multimedia in Arabic language teaching and learning by designing an Arabic vocabulary multimedia courseware 
prototype. Initially, the multimedia functions as a tool in e-learning, integrated in the learning process to enable a more meaningful and enjoyable learning experience for the students. In ensuring the effectiveness in design and execution of this learning tool, its implementation should be handled by educators and experienced trainers, with extensive knowledge and understanding on learner's intrinsic and extrinsic motivations thus producing a successful edutainment environment [7].

\section{Problem Statement}

In addition to English and Malay, the teaching of Arabic language specifically in International Islamic University of Malaysia (IIUM) is made compulsory for all students. The teaching of Arabic language in IIUM has begun since the establishment of IIUM in 1983 at CELPAD, which has used various materials of teaching and learning such as textbooks, audio-visual materials such as cassettes, videos and CDs, flash cards and other limited additional teaching and learning aids [8]. Due to time constraint for students in IIUM to achieve a reasonable proficiency in Arabic before they are allowed to undertake credit-bearing courses at Faculties (Kulliyyah) of main campus, CELPAD has explored the potential of integrating computer technology in the teaching and learning Arabic language by producing an on-line Arabic course. However, there are many challenges and limitations to be faced by Arabic language practitioners in order to maximize the potential of computer technology. One of them is limited materials of designed computer-assisted language learning (CALL) in Arabic available in the market, and technical problems which related to various coding system and authoring packages of courseware developer do not support the Arabic characters [4].

There is still also a lack of computer-assisted technology use in the Arabic language classrooms as indicated by Mohd Feham \& Isarji [4] Mohd Feham [5] and Zawawi [6]. Majority of Arabic language teachers were found to be incompetent in using computer and courseware in teaching process due to poor computer literacy especially among the veteran generations [6] in addition to the difficulty to find Arabic courseware for learning Arabic language [4][5][6]. The researchers also noted that most of the multimedia courseware existing in the field of Arabic language are not designed using appropriate learning theories and appropriate design principles. In light of these prospects, this study will analyze and determine the appropriate design principles for multimedia design and development in teaching and learning Arabic vocabulary.

\section{Research Questions}

This study will find out:

1. What are the suitable learning theories involved in multimedia design and development in teaching and learning Arabic vocabulary?

2. What are the appropriate design principles used for multimedia design and development in teaching and learning Arabic vocabulary?

\section{Methodology}

This study utilizes the qualitative data collection and analysis within the design and development research methodology. The rationale for utilizing methods and approaches of design and development research [9], was to emphasis on both research and practice when producing a valid, practical and effective Arabic vocabulary courseware based on the well-defined and theoretically sound 'design principles'. Iverson for instance suggests the process of design and development of multimedia as a combination of research and practice [10].

The data was collected by using interviews during semester 1 2012/2013 session with various subjects matter experts in teaching Arabic as a second language, syllabus design, computer assisted language learning and instructional design (ID). These subject matter experts' opinions and suggestions are very important in order to sustain the validity of Arabic vocabulary learning contents among non-native learners in this study.

Creswell describes an interview survey as a form on which the researcher records answers supplied by the participants in the study. It also can be used to describe trends to help in identifying important beliefs, attitudes, opinion, behaviors and characteristics of a population [11]. These interviews with the experts involved surveys whereby the researcher used a structured or semi-structured interview consisting of mostly close-ended questions with optional response for interviewees and also through qualitative surveys consisting of open-ended questions without options. Table 1 describes the demographic data of subject matter experts who contributed in this survey. 
Table 1. List of experts

\begin{tabular}{|c|c|c|c|}
\hline No & $\begin{array}{l}\text { Field of Expertise } \\
\end{array}$ & Academic Position & University \\
\hline 1 & $\begin{array}{ll}\text { - } & \text { Teaching Arabic as a Second Language } \\
\text { - } & \text { Syllabus design }\end{array}$ & Asst. Professor & $\begin{array}{l}\text { International Islamic University Malaysia } \\
\text { (IIUM) }\end{array}$ \\
\hline 2 & $\begin{array}{ll}\text { - } & \text { Teaching Arabic as a Second Language } \\
\text { - } & \text { Arabic Linguistics } \\
& \text { Curriculum Development }\end{array}$ & Assoc. Professor & National University of Malaysia (UKM) \\
\hline 3 & $\begin{array}{ll}- & \text { Instructional design (ID) } \\
- & \text { Arabic Language and Information Technology } \\
\text { - } & \text { Computer Assisted Language Learning } \\
\end{array}$ & Assoc. Professor & MARA University of Technology (UiTM) \\
\hline 4 & $\begin{array}{ll}- & \text { Instructional design (ID) } \\
\text { - } & \text { Computer Assisted Language Learning } \\
\text { - } & \text { Second Language Acquisition } \\
\text { - } & \text { Teachers' Training } \\
\end{array}$ & Assoc. Professor & National University of Malaysia (UKM) \\
\hline
\end{tabular}

A survey consists of open-ended and close-ended question was utilized in this study to investigate the validity of theories and design principles for multimedia design and development in teaching and learning Arabic vocabulary. The outcome from this research will later be used by the researchers in the design and development processes. The questions used in this survey are as stated in Table 2.

Table 2. Survey's questions

\begin{tabular}{|c|l|}
\hline No & \multicolumn{1}{|c|}{ Questions } \\
\hline 1 & $\begin{array}{l}\text { Please describe your thought or opinion for designing an } \\
\text { exemplary or suitable design and development theory for } \\
\text { web-based vocabulary multimedia courseware in Arabic } \\
\text { language. }\end{array}$ \\
\hline 2 & $\begin{array}{l}\text { What are the main factors in the design of appropriate } \\
\text { teaching and learning theories in web-based vocabulary } \\
\text { multimedia courseware? }\end{array}$ \\
\hline 3 & $\begin{array}{l}\text { How would you determine suitable learning activities in the } \\
\text { web-based vocabulary multimedia courseware? }\end{array}$ \\
\hline 4 & $\begin{array}{l}\text { Which approaches do you prefer in web-based vocabulary } \\
\text { multimedia courseware? }\end{array}$ \\
\hline 5 & $\begin{array}{l}\text { What are your opinions in the implementation of web-based } \\
\text { vocabulary multimedia courseware in order to improve } \\
\text { students' problem in vocabulary memorization? }\end{array}$ \\
\hline 6 & Do you have any additional suggestion? \\
\hline
\end{tabular}

\section{Results and Findings}

The front end-analysis provides information that can direct the design and development of this Arabic vocabulary multimedia courseware. The summary of experts' in Teaching Arabic as a Second Language detailed responses to the analysis survey can be used for design and development purposes. Table 3 presents the design and development theories as proposed by the experts:
Table 3. Design and development theory

\begin{tabular}{|c|l|}
\hline Expert 1 & $\begin{array}{l}\text { Use everyday vocabulary and vocabulary related } \\
\text { to worship practices (Ibadah) such as prayers, } \\
\text { (God Memorizing) Zikr and supplication and } \\
\text { vocabulary related to food and clothing. }\end{array}$ \\
\hline Expert 2 & $\begin{array}{l}\text { Kindly refer to Social constructivism theory } \\
\text { proposed by Vygotsky (1978). }\end{array}$ \\
\hline Expert 3 & $\begin{array}{l}\text { The designer should provide its own model and } \\
\text { the contents must consist of: } \\
\text { a)Education contents based on syllabus } \\
\text { b)Instructional design (ID) model } \\
\text { c)Devices or means to develop and deploy } \\
\text { applications }\end{array}$ \\
\hline Expert 4 & $\begin{array}{l}\text { Theory of connectivism or theory of cognitivism. } \\
\text { Nowadays more designers used social } \\
\text { constructivism theory proposed by Vygotsky } \\
\text { (1978). Please also consider second language } \\
\text { acquisition theory proposed by Krashen (1984) }\end{array}$ \\
\hline
\end{tabular}

Table 4 shows the main factors in the design of appropriate teaching and learning theories in web-based vocabulary multimedia courseware:

Table 4. Main factors

\begin{tabular}{|l|l|}
\hline Expert 1 & $\begin{array}{l}\text { 1. Educational materials (Pedagogy) and learning } \\
\text { activities. } \\
\text { 2. Types of multimedia inputs (words, images, sounds } \\
\text { and video). }\end{array}$ \\
\hline Expert 2 & $\begin{array}{l}\text { 1. Types of multimedia inputs (words, images, sounds } \\
\text { and video). }\end{array}$ \\
\hline Expert 3 3 & $\begin{array}{l}\text { 1. Educational materials (Pedagogy) and learning } \\
\text { activities. } \\
\text { 2. Types of multimedia inputs (words, images, sounds } \\
\text { and video). }\end{array}$ \\
\hline Expert 4 4 & $\begin{array}{l}\text { 1. Educational materials (Pedagogy) and learning } \\
\text { activities. } \\
\text { 2. Types of multimedia inputs (words, images, sounds } \\
\text { and video). }\end{array}$ \\
\hline
\end{tabular}


Table 5 describes the suitable learning activities in the web-based vocabulary multimedia courseware:

Table 5. Learning activities

\begin{tabular}{|c|c|}
\hline Expert 1 & $\begin{array}{l}\text { 1. Based on multimedia inputs used. } \\
\text { 2. Based on creativity of teachers. }\end{array}$ \\
\hline Expert 2 & $\begin{array}{l}\text { 1. Based on amount of vocabularies taught. } \\
\text { 2. Based on students' needs. }\end{array}$ \\
\hline Expert 3 & 1.Based on amount of vocabularies taught \\
\hline Expert 4 & $\begin{array}{l}\text { 1.Based on types of multimedia inputs used } \\
\text { 2.Based on amount of vocabularies taught } \\
\text { 3.Based on students' needs }\end{array}$ \\
\hline
\end{tabular}

Table 6 demonstrates the preferable approaches in web-based vocabulary multimedia courseware:

Table 6. Approaches

\begin{tabular}{|l|l|}
\hline Expert 1 & $\begin{array}{l}\text { 1.Learner-centered approach } \\
\text { 2.Group learning-centered approach }\end{array}$ \\
\hline Expert 2 & 1.Learner-centered approach \\
\hline \multirow{2}{*}{ Expert 3 } & $\begin{array}{l}\text { 1.Learner-centered approach } \\
\text { 2.Single learning-centered approach }\end{array}$ \\
\hline \multirow{2}{*}{ Expert 4 } & $\begin{array}{l}\text { 1. Teacher-centered approach. } \\
\text { 2. Learner-centered approach. } \\
\text { 3. Single learning-centered approach. } \\
\text { 4. Group learning-centered approach. }\end{array}$ \\
\hline
\end{tabular}

Table 7 presents experts' opinions in the implementation of web-based vocabulary multimedia courseware in order to improve students' problem in vocabulary memorization:

Table 7. Experts' opinions

\begin{tabular}{|c|l|}
\hline $\begin{array}{c}\text { Expert } \\
\mathbf{1}\end{array}$ & $\begin{array}{l}\text { 1. Preparation of advanced educational tools } \\
\text { 2. Use language games to promote the conservation } \\
\text { vocabulary } \\
\text { 3. Organize linguistic competitions }\end{array}$ \\
\hline $\begin{array}{c}\text { Expert } \\
\mathbf{2}\end{array}$ & $\begin{array}{l}\text { 1. Train instructors on how to implement multimedia } \\
\text { through training and workshops. }\end{array}$ \\
\hline $\mathbf{E x p e r t}$ & $\begin{array}{l}\text { 1. The use of multimedia has many purposes, including } \\
\text { addressing the weakness of the students in the study of } \\
\text { vocabulary and memories in new ways. Of course, through } \\
\text { educational programs which include multimedia, students } \\
\text { will show interaction with the computer which shows the } \\
\text { features and capabilities of the students in the present era. }\end{array}$ \\
\hline $\mathbf{E x p e r t}$ & $\begin{array}{l}\text { 1.To include a discussion forum or interactive forum in the } \\
\text { multimedia program } \\
\text { 2. To include instructional design model from experts such } \\
\text { as: Dick \& Carey and Alessi \& Trollip and Gagne in the } \\
\text { multimedia program. }\end{array}$ \\
\hline
\end{tabular}

Table 8 presents experts' additional suggestions related to web-based vocabulary multimedia courseware in Arabic language.
Table 8. Experts' suggestions

\begin{tabular}{|l|l|}
\hline Expert 1 & $\begin{array}{l}\text { 1. Don't rely on a single approach for vocabulary } \\
\text { teaching }\end{array}$ \\
\hline Expert 2 & $\begin{array}{l}\text { 1. Provide extra storage in the courseware to } \\
\text { help students store their materials such as } \\
\text { writings, images, sound recording, video, and } \\
\text { graphs as well as their profiles }\end{array}$ \\
\hline \multirow{2}{*}{ Expert 3 } & $\begin{array}{l}\text { 1. In my opinion, the programs which provide } \\
\text { multimedia design process need creativity to } \\
\text { ensure the effectiveness of the program to its } \\
\text { users. Theories may not help program designers, } \\
\text { but more in some stages of development. }\end{array}$ \\
\hline Expert 4 & $\begin{array}{l}\text { 1. To apply the theory of learning using } \\
\text { multimedia proposed by Mayer (2001) on the } \\
\text { basis of students needs }\end{array}$ \\
\hline
\end{tabular}

\section{Discussions}

Teaching and learning Arabic has long been dominated by the use of conventional methods through lecturing with the help of several tools such as whiteboard, tape recorder, and flash cards. Without neglecting the method applied in conveying this language to learners, which is in this case more or less has become a convention for teaching the language, Arabic language practitioners should somehow integrate the most currently applied to be in coincidence with the students' needs and interests.

Though this is the fact, the application of computer and the web in particular for Arabic is still in its earlier stage. There are many things should be encountered and later settled first before the multimedia courseware can be taken into serious considerations. Some of the matters for instance, theories and design principles, methods of delivery, materials management, and assessment are only but a few in dealing with web-based learning and teaching styles. Even though there are many Arabic vocabulary multimedia courseware have been produced, the researcher found that some of these courseware were not developed based on the educational theories and design principles.

Hence this study encompasses the theories and design principles for design and development of multimedia courseware for teaching and learning Arabic vocabulary. This kind of information is important to produce an Arabic vocabulary courseware based on learning needs of teaching and learning tools in Arabic language as mentioned in the problem statement.

The theoretical contribution of this study can be concluded in the formulation of the design principles that are selected and adapted from review by the subject matter experts'. The subject matter experts propose the implementation of social constructivism theory, theory of second language acquisition and theory of multimedia learning [12][13][14]. 
In order to understand how social constructivism can be applied in the design and development of an Arabic vocabulary multimedia courseware, it is important to understand the concept of social studies. Social constructivism requires one primary element; two or more students. These students must be involved in some form of interaction for knowledge to be constructed. The participants must come together in some form of interaction with some knowledge of prior social experience. The participants then engage in some form of interaction, generally by use of language or actions. Social constructivism provides ideas to help the authors to create an Arabic vocabulary multimedia courseware with learner-centered and collaborative environments that support critical reflection and experiential processes. From the standpoint of supporting language acquisition, this Arabic vocabulary multimedia courseware should offer functionality that facilitates connections between online and offline activities. For instance, to facilitate the writing process, the courseware should be designed to support peer review, editing, and rewriting. In addition, tools for creating five types of language activities such as vocabulary assignment, discussion forum, quiz, essay, and self-test exercise must be taken into account. Instructors can organize these activities in a chronological menu. All activities can be hidden during development process and released when the instructor wants.

The research framework by using a modified ADDIE model of instructional design, the research process strategies used and adapted in this study are also part and parcel of cyclic and iterative methods of design and development in game-based learning that can be adapted by future research efforts.

\section{Conclusions}

The practical contribution of this study is the production of design and development framework for Arabic vocabulary multimedia courseware which can be used based on related educational theories, design and development research methods, learning and contextual analysis of needs. This study mainly adopts a method of qualitative research exemplifying an in depth and breadth phenomenon and explanation on theories and characteristics of a valid, practical and effective Arabic vocabulary learning as perceived by users. Thus the findings cannot be generalized but some of the designs and development principles may be applied in a similar setting and to be emulated by other institutions as well based on their situational learning problems and issues.

However the different set of 'design principles' may appear in the other settings because this study focuses only on Arabic learners at elementary level with a specific course outline of syllabus, and most of the learners involved in this study are non-native speakers of Arabic language. This study puts forward a set of design and development principles for an Arabic vocabulary multimedia courseware in Malaysian context specifically and for non-native Arab students in general.

\section{Acknowledgements}

We gratefully acknowledge the support and generosity of Universiti Sains Islam Malaysia (USIM) and International Islamic University Malaysia (IIUM) for the cooperation and data collection in this paper until its completion.

\section{REFERENCES}

[1] Davis, N. \& Somekh, B., Using Information Technology Effectively in Teaching and Learning. London: Routledge. 1997.

[2] Mohamed Amin, E., Muhammad Kamarul, K., \& Norizan, A.R., Readings in Online Language Learning and Teaching, Research and Practice. Selangor, Malaysia: Karisma Publications Sdn Bhd. 2008.

[3] Nurkhamimi, Z. \& Muhammad Sabri, S. "Development of Arabic case system online tutorial using screen capture software." Australian Journal of Basic and Applied Sciences 8, no. 4. 2014. pp. 774-780.

[4] Mohd Feham, G. \& Isarji, S., On-line Arabic: Challenges, Limitations, and Recommendations. In proceedings of National Conference On Teaching and Learning in Higher Education,Universiti Utara Malaysia, Kedah. 2000.

[5] Mohd Feham. The design, development and testing on the efficacy of a pedagogical agent on the performance and program rating scores among students learning Arabic. Unpublished Doctoral Dissertation, Universiti Sains Malaysia (USM). 2006.

[6] Zawawi, Ismail., Penilaian Pelaksanaan Kurikulum Kemahiran Bertutur Bahasa Arab Komunikasi di Sekolah Menengah Kebangsaan Agama. Unpublished PhD Thesis, Universiti Kebangsaan Malaysia. 2008.

[7] Zarina Che Embi, \& Hanafizan Hussain., Analysis of local and foreign edutainment products - An effort to implement the design framework for an edutainment environment in Malaysia. Multimedia University, Malaysia. The Journal of Computers in Mathematics and Science Teaching, 24(1), 2005, ProQuest Education Journals, 27-42.

[8] Md Nasir Omar., Pengajaran Bahasa Arab Kepada Pelajar-pelajar Peringkat Permulaan di Pusat Matrikulasi Universiti Islam Antarabangsa Malaysia - The Arabic Language Teaching to Students at Matriculation Centre, International Islamic University Malaysia. Unpublished Masters Thesis, University of Malaya, Kuala Lumpur. 1996.

[9] Richey, R.C., \& Klein, J.D., Design and development research. New Jersey, USA: Lawrence Erlbaum Associates, Inc. 2007.

[10] Iverson, K. M., E-learning games, interactive learning strategies for digital delivery. New Jersey, USA: Pearson Education, Inc. 2005. 
[11] Creswell, J.W., Educational research - planning, conducting, and evaluating quantitative and qualitative research. (2nd ed.). New Jersey, USA: Pearson Education International. 2005.

[12] Vygotsky, L., Mind in Society: The Development of Higher Psychological Processes, Cambridge, MA: Harvard
University Press. 1978.

[13] Krashen, Stephen, D., Writing: Research, Theory and Application. Oxford: Pergamon Press. 1984.

[14] Mayer, R.E., Multimedia Learning, Cambridge, UK: Cambridge University Press. 2001. 